J. Perinat. Med.

13 (1985) 23

\section{Effects of betamethasone and ritodrine on the fetal secretion of lung surfactant}

\author{
M. Hallman, K. Teramo*, S. Sipinen*, K. Raivio
}

Childrens' Hospital, University of Helsinki, Helsinki, Finland, and

* I and II Departments of Obstetrics and Gynecology, University of Helsinki, Finland

\section{Introduction}

A decrease in the incidence of respiratory distress syndrome (RDS) in the newborn following maternal glucocorticoid treatment has been documented by LIGGINS and HowIE $[20,21]$, and confirmed by others $[5,8,23,29]$. Experimental studies have shown that glucocorticoid therapy stimulates the synthesis $[1,25-27]$ and secretion $[9,10,24]$ of the major surfactant component, disaturated lecithin.

Beta-sympathomimetic drugs are widely used to prevent premature uterine activity. These drugs cross the placenta [30] and may thus affect fetal organs including the lung. Following betasympathomimetic drug administration in premature labor, the incidence of RDS has been reported to increase [7], to decrease [6], or to remain unaltered [20]. Beta-sympathomimetic stimulation increases the secretion of surfactant from its intracellular storage in adults [22] and in fetuses [9, 11, 32]. In addition, a beta-sympathomimetic drug decreases the secretion rate of fetal lung fluid [31]. In the present study we have investigated the effect of a glucocorticoid agent and a beta-sympathomimetic drug on the phos-

Tab. I. Protocol of the drug treatments

\begin{tabular}{|c|c|c|c|}
\hline Drug & Dosage & Age and Route of Administration & Time of Evaluation \\
\hline $\begin{array}{l}\text { A. Betamethasone } \\
\text { B. None }\end{array}$ & $0.24 \mathrm{mg}$ & Intramuscularly to 26.8 day-old fetus & $\begin{array}{l}\text { Five min from delivery, day } 28.7 \\
\text { Same as A. Littermate to A }\end{array}$ \\
\hline $\begin{array}{l}\text { C. Saline } \\
\text { D. None }\end{array}$ & $0.05 \mathrm{ml}$ & Intramuscularly to 26.8 day-old fetus & $\begin{array}{l}\text { Five min from delivery, day } 28.7 \\
\text { Five min from delivery, day } 28.7 \text {. } \\
\text { Littermate to C. }\end{array}$ \\
\hline $\begin{array}{l}\text { E. Ritodrine } \\
\text { F. Saline }\end{array}$ & $\begin{array}{l}0.8 \mathrm{mg} \text {, } \\
\text { every } 6 \mathrm{~h} \\
0.5 \mathrm{ml} \\
\text { every } 6 \mathrm{~h}\end{array}$ & $\begin{array}{l}\text { Intramuscularly to the doe, days } 26.8-28.5 \\
\text { Same as E. }\end{array}$ & $\begin{array}{l}30 \text { min from delivery, day } 28.7 \\
\text { Same as } \mathrm{E}\end{array}$ \\
\hline G. Ritodrine & $0.5 \mathrm{mg}$ & $\begin{array}{l}\text { Intramuscularly to } 27.8 \text { day-old fetus, } \\
\text { 2nd time intraperitoneally to } 28.7 \text { day-old } \\
\text { fetus at delivery }\end{array}$ & Same as $\mathrm{E}$. \\
\hline H. Ritodrine & $0.5 \mathrm{mg}$ & $\begin{array}{l}\text { Intraperitoneally to } 28.7 \text { day-old fetus } \\
\text { at delivery }\end{array}$ & $\begin{array}{l}\text { Same as } E \text {. } \\
\text { Littermate to } G \text {. }\end{array}$ \\
\hline
\end{tabular}


pholipids of the alveolar lavage fluid from premature rabbits in order to evaluate whether both these drugs accelerate fetal lung maturation.

\section{Materials and methods}

New Zealand albino rabbits were used. The time of conception was known within \pm 4 hours. The protocols for the administration of the drugs are shown in Tab. I. The number of fetuses (does) in each study group was as follows: A: 34 (20); B: 63 (20); C: 16 (8); D: 55 (8); E: 20 (3); F: 25 (4); G: 20 (10); H: 27 (10). The pregnant does were operated upon under local anesthesia using 3-4 ml of $0.25 \%$ of lidocaine without adrenalin. Betamethasone sodium phosphate $(0.12 \mathrm{mg})$ and betamethasone acetate $(0.12 \mathrm{mg})$ (Celestone Chronodose $^{\circledR}$, Schering Corp), ritodrine hydrochloride (0.5 mg) (Utopar ${ }^{\circledR}$, Ferrosan), or $0.9 \%$ saline were given intramuscularly in $0.05 \mathrm{ml}$ to the fetus. Following the drug injections, $0.02-0.03 \mathrm{ml}$ of barium sulfate was injected intramuscularly, in order to identify the drug-exposed fetuses by radiography after the experiment. One to two fetuses received the injection and the littermates served as controls. The fetuses were removed from the uterus by cesarean section under local anesthesia, and the umbilical cord was cut. The position of the individual fetuses in the uterine horns was identified. The newborn animals were kept in room air at $25^{\circ} \mathrm{C}$, and were allowed to breathe for 5 or 30 minutes (Tab. I).

Following the intracerebral injection of $0.1 \mathrm{ml}$ of phenobarbital, the airways were lavaged as described previously [15]. The total lipid fraction was isolated according to BLIGH and DYER [4]. An aliquot was taken for analysis of disaturated phosphatidylcholine [15]. The rest were analyzed by two-dimensional thin-layer chromatography and the individual phospholipids were quantified by measuring their phosphorus contents [15]. For each phospholipid analysis, lavages from three to four fetuses were pooled. The results were expressed as the mean $\pm \mathrm{SEM}$, and the statistical significance was calculated using the t-test.

\section{Results}

3.1 Effect of glucocorticoid treatment: Betamethasone administration decreased the body

Tab. II. Effect of betamethasone on the recovery of phospholipids in the lung lavage fluid

\begin{tabular}{|c|c|c|c|c|c|c|}
\hline & \multirow{2}{*}{$\begin{array}{l}\text { Group A }^{1} \\
\text { Betamethasone }\end{array}$} & \multirow{2}{*}{$\begin{array}{l}\text { Group } \mathrm{B}^{1} \\
\text { Control, } \\
\text { Littermate to A }\end{array}$} & \multirow{2}{*}{$\begin{array}{l}\text { Group } C^{1} \\
\text { Saline Control }\end{array}$} & \multicolumn{3}{|l|}{$\mathbf{P}$} \\
\hline & & & & \multirow[t]{2}{*}{ A vs $B$} & \multirow[t]{2}{*}{ A vs $C$} & \multirow[t]{2}{*}{ B vs $\mathrm{C}$} \\
\hline & \multicolumn{3}{|c|}{ nmoles phospholipid/g body weight } & & & \\
\hline $\begin{array}{l}\text { Total } \\
\text { phospholipid }{ }^{2}\end{array}$ & $7.65 \pm 1.01(6)^{3}$ & $5.10 \pm 0.35(8)^{3}$ & $6.20 \pm 0.88(5)^{3}$ & $<0.025$ & & \\
\hline $\begin{array}{l}\text { Phosphat- } \\
\text { idylcholine }\end{array}$ & $5.40 \pm 0.40$ & $3.47 \pm 0.20$ & $4.27 \pm 0.41$ & $<0.005$ & & \\
\hline $\begin{array}{l}\text { Disaturated } \\
\text { Phosphat- } \\
\text { idylcholine }\end{array}$ & $2.95 \pm 0.24$ & $1.70 \pm 0.12$ & $2.27 \pm 0.22$ & $<0.001$ & $<0.05$ & $<0.025$ \\
\hline $\begin{array}{l}\text { Phosphat- } \\
\text { idylinositol }\end{array}$ & $0.85 \pm 0.05$ & $0.43 \pm 0.03$ & $0.52 \pm 0.04$ & $<0.001$ & $<0.001$ & $<0.05$ \\
\hline $\begin{array}{l}\text { Phosphat- } \\
\text { idylserine }\end{array}$ & $0.22 \pm 0.02$ & $0.21 \pm 0.01$ & $0.22 \pm 0.02$ & & & \\
\hline Sphingomyelin & $0.70 \pm 0.05$ & $0.64 \pm 0.02$ & $0.73 \pm 0.05$ & & & \\
\hline
\end{tabular}

1 The treatment protocols are shown in Tab. I: A, B, and C.

2 The sum of phosphatidylcholine, phosphatidylinositol, phosphatidylserine, phosphatidylethanolamine, bis-(monoacylglycerol) phosphate, phosphatidylglycerol, and sphingomyelin.

3 Mean \pm SEM (number of analyses). 
weight (betamethasone: $29.3 \pm 0.6 \mathrm{~g}$; littermate control: $34.0 \pm 0.5 \mathrm{~g}, \mathrm{p}<0.001$ ), and the dry weight of the lungs $(0.202 \pm 0.008 \mathrm{~g}$; control: $0.241 \pm 0.010 \mathrm{~g}, \mathrm{p}<0.02$ ). There was no significant difference in the lung dry weight/total body weight ratio as compared between the two groups (0.0065 \pm 0.0003 , control: $0.0066 \pm 0.0006)$. Injection of saline and barium sulfate to the fetus had no effect on the body or lung weights of the fetus (data not shown).

The recovery of the phospholipids in alveolar lavage following betamethasone treatment is shown in Tab. II except the data for phosphatidylglycerol, phosphatidylethanolamine, and bis- (monoacylglycerol) phosphate. Betamethasone significantly increased the recovery of total phospholipid, phosphatidylcholine, disiturated phosphatidylcholine and phosphatidylinositol as compared to littermate controls, and increased disaturated phos. phatidylcholine and phosphatidylinositol as con. pared to saline treated controls. The drug had no significant effect on the other phospholipids.
The effect of betamethasone on the phospholipid composition is shown in Tab. III. The drug increased disaturated phosphatidylcholine/sphingomyelin ratio and phosphatidylinositol. In addition, betamethasone decreased phosphatidylserine as compared to littermate controls. Saline injection to the fetus had no significant effect on the quality or quantity of alveolar lavage phospholipids, as compared to the littermales (data not shown).

3.2 Effect of beta-sympathomimetic drug treatment: A low dose of ritodrine, injected in to the doe, had no effect on either the various phospholipid fractions of the alveolar lavage (Tab. IV), or the recovery of total phospholipid (ritodrine: $5.3 \pm 0.8 \mathrm{nmoles} / \mathrm{g}$ body weight; salinc-control: $5.1 \pm 0.6 \mathrm{nmoles} / \mathrm{g}$ body weight), or the recovery of individual phospholipids (data not shown).

In another experiment, ritodrine was given directly to the fetus and to the premature newborn at

Tab. III. Effect of betamethasone on the phospholipid composition of the lavage fluid.

\begin{tabular}{|c|c|c|c|c|c|c|}
\hline & \multirow{2}{*}{$\begin{array}{l}\text { Group } A^{1} \\
\text { Betamethasone }\end{array}$} & \multirow{2}{*}{$\begin{array}{l}\text { Group B' } \\
\text { Control, } \\
\text { Littermate to A }\end{array}$} & \multirow{2}{*}{$\begin{array}{l}\text { Group } C^{\prime} \\
\text { Saline control }\end{array}$} & \multicolumn{3}{|l|}{$\mathbf{P}$} \\
\hline & & & & $A$ vs $B$ & A vs $C$ & B vs $C$ \\
\hline $\begin{array}{l}\text { Phosphat- } \\
\text { idylcholine }\end{array}$ & $72.7 \pm 1.7 \%(6)^{2}$ & $69.4 \pm 1.4 \%(8)^{2}$ & $70.8 \pm 1.7 \%(6)^{2}$ & & & \\
\hline $\begin{array}{l}\text { Phosphat- } \\
\text { idylinositol }\end{array}$ & $10.7 \pm 0.6 \%$ & $8.2 \pm 0.7 \%$ & $8.9 \pm 0.8 \%$ & $<0.01$ & $<0.05$ & \\
\hline $\begin{array}{l}\text { Phosphat- } \\
\text { idylglycerol }\end{array}$ & $0.5 \pm 0.3 \%$ & $0.3 \pm 0.1 \%$ & $0.5 \pm 0.2 \%$ & & & \\
\hline $\begin{array}{l}\text { Phosphat- } \\
\text { idylserine }\end{array}$ & $1.9 \pm 0.3 \%$ & $3.1 \pm 0.4 \%$ & $2.4 \pm 0.3 \%$ & $<0.025$ & & \\
\hline $\begin{array}{l}\text { Phosphatidyl- } \\
\text { ethanolamine }\end{array}$ & $3.9 \pm 0.5 \%$ & $5.0 \pm 0.4 \%$ & $4.2 \pm 0.4 \%$ & & & \\
\hline $\begin{array}{l}\text { Bis- } \\
\text { (monoacylglycerol) } \\
\text { phosphate }\end{array}$ & $0.3 \pm 0.1 \%$ & $0.6 \pm 0.2 \%$ & $0.4 \pm 0.2 \%$ & & & \\
\hline Sphingomyelin & $10.0 \pm 1.6 \%$ & $13.4 \pm 4.0 \%$ & $12.8 \pm 2.9 \%$ & & & \\
\hline Total & $100.0 \quad \%$ & 100.0 & 100.0 & & & \\
\hline $\begin{array}{l}\text { Disaturated } \\
\text { phosphat- } \\
\text { idylcholine/ } \\
\text { Sphingomyelin } \\
\text { ratio }\end{array}$ & $3.9 \pm 0.3$ & $2.2 \pm 0.3$ & $2.6 \pm 0.2$ & $<0.005$ & $<0.01$ & \\
\hline
\end{tabular}

1 The treatment protocols are shown in Tab. I: A, B, and C.

2 Mean \pm SEM (number of analyses). 
birth. The littermates that received ritodrine at birth served as controls (Tab. I: G, H). Ritodrine administration to the fetus and to the newborn significantly decreased the recovery of phosphatidylinositol $(0.42 \pm 0.04 \mathrm{nmoles} / \mathrm{g}$ body weight; control, ritodrine at birth: $0.58 \pm 0.04 \mathrm{nmoles} / \mathrm{g}$ body weight, $\mathrm{p}<0.02$ ), but had no significant effect on the total phospholipid recovery ( $4.9 \pm 0.3 \mathrm{nmoles} / \mathrm{g}$ body weight; control: $5.4 \pm 0.3 \mathrm{nmoles} / \mathrm{g}$ body weight), or on the other phospholipids (data not shown). Ritodrine administration to the fetus decreased phosphatidylinositol/sphingomyelin and disaturated phosphatidylcholine/sphingomyelin ratios (Tab. V). The drug did not alter the total body weight or the dry weight of the lung (data not shown).

Ritodrine given to the fetus and at birth (group G) decreased phosphatidylinositol/sphingomyelin ( $p<0.02)$, and disaturated phosphatidylcholine/ sphingomyelin ratios $(\mathrm{p}<0.05)$, as compared to the offspring of the saline treated does (group F). The lavage phospholipids in the newborns that were treated with ritodrine at birth (group $\mathrm{H}$ ) were not significantly different from phospholipids in the offspring of the saline treated does (group F).

\section{Discussion}

In the present study it was demonstrated that betamethasone administration to the immature fetus increases both surfactant phosphatidyl- choline and phosphatidylinositol. As shown by FELDMAN et al., only phosphatidylglycerol exceeds the capacity of phosphatidylinositol to activate lung phosphocholine cytidyltransferase which presumably is a rate limiting enzyme in phosphatidylcholine synthesis [12]. In addition, both phosphatidylglycerol and phosphatidylinositol promote the absorption of disaturated phosphatidylcholine from subphase to the surface [17]. This is important in terms of surfactant function [2]. Therefore, the observed increase in surfactant phosphatidylinositol seems to explain further the mechanism of glucocorticoids in accelerating the lung maturation and preventing RDS.

Beta-sympatomimetic drugs may improve neonatal respiratory adaptation by decreasing fetal lung fluid secretion $[18,31]$ or by promoting the secretion of lung surfactant $[11,32]$.

It has been proposed that both glucocorticoids and sympathomimetic drugs affect lung maturation by a mechanism, that increases intracellular cyclic AMP [3]. However, it is unlikely that the glucocorticoid effect is solely based upon interaction with cyclic AMP system [14].

We found that ritodrine did not increase surfactant, when given at birth. Since beta-sympatomimetic drugs acutely increase surfactant secretion in the rabbit fetus of comparable gestational age [11, 30] it is likely that the lack of effect at birth was due to high endogenous adrenergic activity. On the other hand the failure of maternal ritodrine to affect fetal surfactant phospholipids may be solely

Tab. IV. Effect of maternal ritodrine on the phospholipid composition of the lavage fluid.

\begin{tabular}{|c|c|c|}
\hline & $\begin{array}{l}\text { Group } E^{1} \\
\text { Ritodrine }\end{array}$ & $\begin{array}{l}\text { Group } \mathrm{F}^{1} \\
\text { Saline control }\end{array}$ \\
\hline $\begin{array}{l}\text { Phosphatidylcholine } \\
\text { Phosphatidylinositol } \\
\text { Phosphatidylglycerol } \\
\text { Phosphatidylserine } \\
\text { Phosphatidylethanolamine } \\
\text { Bis-(monoacylglycerol) phosphate } \\
\text { Sphingomyelin } \\
\text { Total }\end{array}$ & $\begin{aligned} 70.2 & \pm 0.9 \%(6)^{2} \\
9.3 & \pm 0.8 \% \\
0.4 & \pm 0.1 \% \\
2.6 & \pm 0.3 \% \\
4.8 & \pm 0.5 \% \\
0.4 & \pm 0.0 \% \\
12.3 & \pm 2.2 \% \\
100 & \%\end{aligned}$ & $\begin{aligned} & 69.9 \pm 2.9 \%(8)^{2} \\
& 9.0 \pm 1.3 \% \\
& 0.6 \pm 0.1 \% \\
& 2.9 \pm 0.1 \% \\
& 4.8 \pm 0.4 \% \\
& 0.3 \pm 0.1 \% \\
& 12.5 \pm 0.9 \% \\
& 100 \quad \%\end{aligned}$ \\
\hline $\begin{array}{l}\text { Phosphatidylinositol/sphingomyelin ratio } \\
\text { Disaturated phosphatidylcholine sphingomyelin ratio }\end{array}$ & $\begin{array}{l}0.8 \pm 0.05 \\
2.7 \pm 0.6\end{array}$ & $\begin{array}{l}0.8 \pm 0.1 \\
2.6 \pm 0.2\end{array}$ \\
\hline
\end{tabular}

1 The treatment protocols are shown in Tab. I: E and F.

${ }^{2}$ Mean \pm SEM (number of analyses). 
Tab. V. The phospholipid composition of the lavage fluid after ritodrine to the fetus.

\begin{tabular}{|c|c|c|c|}
\hline & Group G & Group H & $\mathbf{P}$ \\
\hline & $\begin{array}{l}\text { Ritodrine } \\
\text { to fetus and at birth }\end{array}$ & $\begin{array}{l}\text { Ritodrine } \\
\text { at birth }\end{array}$ & \\
\hline $\begin{array}{l}\text { Phosphatidylcholine } \\
\text { Phosphatidylinositol } \\
\text { Phosphatidylglycerol } \\
\text { Phosphatidylserine } \\
\text { Phosphatidylethanolamine } \\
\text { Bis-(monoacylglycerol) phosphate } \\
\text { Sphingomyelin } \\
\text { Total }\end{array}$ & $\begin{aligned} 67.9 & \pm 3.1 \%(6)^{2} \\
7.3 & \pm 0.6 \% \\
0.4 & \pm 0.1 \% \\
3.4 & \pm 0.7 \% \\
4.9 & \pm 0.4 \% \\
0.7 & \pm 0.2 \% \\
15.4 & \pm 1.7 \% \\
100 & \%\end{aligned}$ & $\begin{aligned} 69.4 & \pm 2.3 \%(7)^{2} \\
9.5 & \pm 0.8 \% \\
0.6 & \pm 0.1 \% \\
2.4 & \pm 0.3 \% \\
4.1 & \pm 0.3 \% \\
0.6 & \pm 0.1 \% \\
13.4 & \pm 1.5 \% \\
100 & \%\end{aligned}$ & $<0.025$ \\
\hline $\begin{array}{l}\text { Phosphatidylinositol/sphingomyelin ratio } \\
\text { Disaturated phosphatidylcholine/sphingomyelin ratio }\end{array}$ & $\begin{array}{l}0.5 \pm 0.04 \\
1.9 \pm 0.2\end{array}$ & $\begin{array}{l}0.8 \pm 0.1 \\
2.5 \pm 0.3\end{array}$ & $\begin{array}{l}<0.01 \\
<0.05\end{array}$ \\
\hline
\end{tabular}

1 The treatment protocols are shown in Tab. I, G and $H$.

${ }^{2}$ Mean \pm SEM (number of analyses).

due to the low dose of the drug. The decrease in disaturated phosphatidylcholine/sphingomyelin ratio and phosphatidylinositol following the high dose of ritodrine (Tab. V) can be due to premature release of surfactant to fetal lung fluid without a compensatory increase in surfactant synthesis $[14,16]$, or due to beta-sympathomimetic-induced hyperinsulinemia and hyperglycemia [28].

The present and previous results demonstrate that, depending on the dosage and time of administra- tion, beta-adrenergic drugs may increase, decrease, or have little effect on the surfactant secretion. This helps to explain the controversy concerning the influence of the sympathomimetic drugs on the incidence of RDS [6, 7, 20]. Since labor may be associated with acceleration of lung maturation [13], and beta-sympathomimetics delay the premature delivery in some cases, the present data does not contradict the use of small to moderate doses of beta-adrenergic drugs in threatened premature labor.

\section{Summary}

Beta-sympathomimetic drugs and glucocorticoid agents are given in preterm labor to prevent severe consequences of prematurity. It is unclear whether beta-sympathomimetics accelerate lung maturation, or whether they only tend to delay preterm delivery. We have evaluated the effects of betamethasone and ritodrine in rabbits on alveolar lavage phospholipids in premature rabbits, a mean of 28.7 days from conception. Betamethasone given to 26-day-old fetuses increased the surfactant phospholipids, phosphatidylinositol and disaturated phosphatidylcholine; increased disaturated phosphatidylcholine/sphingomyelin ratio, and phosphatidylinositol (percent of phospholipids), as compared to untreated littermates, or to saline treated controls. A low dose of ritodrine given to the pregnant doe, and a high dose given at premature birth had no detectable effects on alveolar lavage phospholipids. However, a high dose of ritodrine given one day before the delivery to the fetus and at premature birth decreased the disaturated phosphatidylcholine/sphingomyelin ratio and phosphatidylinositol in alveolar lavage. While glucocorticoid administration increases the synthesis and secretion of surfactant phospholipids, a high dose of a betasympathomimetic drug may decrease the surfactant. However, spontaneous premature labor is associated with accelerated lung maturation, and accordingly the present results do not contradict the use of a low dosage of betasympathomimetic drug to delay preterm delivery.

Keywords: Betamethasone, lecithin/sphingomyelin ratio, lung surfactant, phosphatidylcholine, phosphatidylinositol, preterm infant, respiratory distress syndrome, ritodrine. 


\section{Zusammenfassung}

Einfluß von Betamethason und Ritodrin auf die Sekretion des Lungensurfactant beim Feten

Bei Frühgeburten werden Betasympathomimetika und Glukokortikoide zur Vermeidung durch Unreife bedingter schwerer Komplikationen verabreicht. Es ist nicht geklärt, ob Betasympathomimetika die Lungenreifung beschleunigen oder ob sie lediglich die Frühgeburt verzögern. Wir untersuchten den Einfluß von Betamethason und Ritodrin auf die Phospholipide in der Alveolarlavage bei frühgeborenen Kaninchen, die im Durchschnitt 28,7 Tage post conceptionem geboren wurden. Wurde bei einer Tragzeit von 26 Tagen Betamethason verabreicht, kam es zu einem Anstieg der Oberflächenphospholipide/Phosphatidylinositol und des doppelgesättigten Phosphatidylcholins. Auch die Phosphatidylcholin/Sphingomyelin-Ratio wie auch das Phosphatidylinositol (in \% der Phospholipide) stieg im Vergleich zu unbehandelten bzw. mit $\mathrm{NaCl}$ behandelten
Kontrolltieren. Eine dem trächtigen Muttertier verabreichte niedrige Ritodrindosis wie auch eine hohe Dosis, die in der Phase der Frühgeburt gegeben wurde, hatten keinen nachweisbaren Einfluß auf die Phospholipide in der Alveolarlavage. Wurde Ritodrin jedoch in hoher Dosierung einen Tag vor der Geburt an den Feten sowie bei der Frühgeburt verabreicht, kam es zu einem Abfall der Ratio von doppelgesättigten Phosphatidylcholinen und Sphingomyelinen sowie des Phosphatidylinositols in der Aleolarlavage. Während Glukokortikoide die Synthese und Sekretion von oberflächenaktiven Phospholipiden stimulieren, haben Betasympathomimetika in hoher Dosierung einen gegenteiligen Effekt. Eine spontane Frühgeburt geht jedoch mit einer beschleunigten Lungenreifung einher. Die vorliegenden Ergebnisse sprechen nicht gegen den Einsatz von Betasympathomimetika in niedriger Dosierung zur Verzögerung einer Frühgeburt.

Schlüsselwörter: Betamethason, Frühgeborenes, Lezithin/Sphingomyelin-Ratio, Lungensurfactant, Phosphatidylcholin, Phosphatidylinositol, respiratorisches Distress-Syndrom, Ritodrin.

Résumé

Effets de la bétamethasone et de la ritodrine sur la sécrétion du surfactant pulmonaire chez la fœtus

On utilise les bétamimétiques et les glucocorticoïdes au cours de l'accouchement prématuré pour éviter les conséquences sévères de la prématurité. On ne sait pas précisément si les bétamimétiques accélèrent la maturation pulmonaire, ou si ils retardent seulement le terme de l'accouchement prématuré.

Nous avons déterminé les effets de la bétamethasone et de la ritodrine sur les phospholipides alvéolaires receuillis par lavage chez les lapins prématurés, nés en moyenne 28,7 jours aprés la conception. La bétaméthasone, donnée aux fœtus de 26 jours augmente les phospholipides du surfactant, phosphatidylinositol et phosphatidylcholine disaturé; le rapport phosphatidylcholine disaturé sur sphingomyéline et le phosphatidyl Inositol (\% de phospholipides) sont augmentés par rapport aux autres membres de la portée non traités ou aux témoins traités par du sérum salé. Une faible dose de ritodrine administrée à la lapine ou une forte dose administrée lors de l'accouchement prématuré n'a pas d'effet détectable sur les phospholipides alvéolaires obtenus par lavage.

Toutefois. une dose élevée de ritodrine, administrée au fœtus un jour avant la naissance et lors de l'accouchement prématuré, diminue le rapport phosphatidylcholine disaturé sur sphingomyéline et le phosphatidylinositol du liquide de lavage alvéolaire. Alors que les glucocorticoïdes augmentent la synthèse et la sécrétion des phospholipides du surfactant, une dose élevée de bétamimétique peut diminuer le surfactant.

Néanmoins, l'accouchement prématuré spontané s'accompagne d'une accélération de la maturation pulmonaire et en outre, nos résultats ne contre-indiquent pas l'utilisation des bétamimétiques à doses faibles dans le but de retarder l'accouchement prématuré.

Mots-clés: Bétamethasone, phosphatidylcholine, phosphatidylinositol, prematurés, rapport lecithine/sphingomyéline, ritodrine, surfactant pulmonaire, syndrome de detresse respiratoire.

\section{Bibliography}

[1] BALLARD, P. L., B.J. BENSON, A. BREHIER: Glucocorticoid effects in the fetal lung. Am. Rev. Respir. Dis. 115 (1977) 29

[2] BANGHAM, A. D., C. J. MORLEY, M. C. PHILliPS: The physical properties of an effective lung surfactant. Biochim Biophys. Acta. 573 (1979) 552

[3] BARRETT, C. T.: Cyclic AMP: Accelerator in lung maturation. In: Proceedings of the 70th Ross Con- ference on Pediatric Research. Ross Laboratories, Ohio 1976, pp. 41-42

[4] BLIGH, E. G., W. J. DYER: A rapid method for total lipid extraction and purification. Can.J. Biochem. Physiol. 37 (1959) 911

[5] BLOCK, M.F., O.R. KLING, W. M. CROSBY: Antenatal glucocorticoid therapy for the prevention of respiratory distress syndrome in the premature infant. Obstet. Gynecol. 50 (1977) 186 
[6] BOOG, G., M. B. BRAHIM, R. GANDAR: Betamimetic drugs and possible prevention of respiratory distress syndrome. Br. J. Obstet. Gynecol. 82 (1975) 285

[7] BRAZY, J. E., M. J. PUPKIN : Effects of maternal isoxsuprine administration on preterm infants. J. Pediatr. 94 (1979) 444

[8] Collaborative group on antenatal steroid therapy: Effect of antenatal dexamethasone administration on the prevention of respiratory distress syndrome. Am. J. Obstet. Gynecol. 141 (1981) 276

[9] CORBET, A. J. S., P. FLAX, A. J. RUDOLPH: Role of autonomic nervous system controlling surface tension in fetal rabbit lungs. J. Appl. Physiol. 43 (1977) 1039

[10] DELEMOS, R. A., D. W.SHERMETA, J.H.KNELSON et al.: Induction of pulmonary surfactant in the fetal lamb by hydrocortisone. Pediatr. Res. 3 (1969) 505

[11] ENHORNING, G., D. CHAMBERLAIN, C. CONTRERAS et al.: Isoxsuprine infusion to the pregnant rabbit and its effect on fetal lung surfactant. Biol. Neonat. 35 (1979) 43

[12] FELDMAN, D. A., C. R. KOVAC, P. L. DRANGINIS et al.: The role of phosphatidylglycerol in the activation of CTP: phosphocholine cytidyltransferase from rat lung. J. Biol. Chem. 253 (1978) 4980

[13] FREDRICK, J., N. R. BUTLER: Hyaline-membrane disease. The Lancet 2 (1972) 768

[14] GROSS, I.: The hormonal regulation of fetal lung maturation. Clinic. Perinatol. 6 (1979) 377

[15] HALLMAN, M., L. GLUCK: Formation of acidic phospholipids in rabbit lung during perinatal development. Pediatr. Res. 14 (1980) 1250

[16] HAYDEN, W., E. B. OLSON, R. D. ZACHMAN: Effect of maternal isoxsuprine on fetal rabbit lung biochemical maturation. Am. J. Obstet. Gynecol. 129 (1977) 691

[17] JACOB, J., M. HALLMAN, L. GLUCK: Phosphatidylinositol (PI) and phosphatidylglycerol (PG) enhance surface active properties of lecithin (PC). Pediatr. Res. 14 (1980) 644

[18] KITTERMAN, J.A.; P. L. BALlaRD, J. A. CleMENTS et al.: Tracheal fluid in fetal lambs: spontaneous decrease prior to birth. J. Appl. Physiol.: Respirat. Environ. Exercise Physiol. 47 (1979) 985

[19] KOTAS, R. V., M. E. AVERY: Accelerated appearance of pulmonary surfactant in the fetal rabbit. J. Appl. Physiol. 30 (1971) 358

[20] LIGGINS, G. C.: The prevention of RDS by maternal betamethasone administration. In: Proceedings of the 70th Ross Conference on Pediatric Research, Ross Laboratories, Ohio 1976, pp. 97-105

[21] LIGGINS, G. C., R. N. HOWIE: A controlled trial of antepartum glucocorticoid treatment for prevention of the respiratory distress syndrome in premature infants. Pediatrics 50 (1972) 515
[22] OYARzUN, M. J., J. A. CLEMENTS: Control of lung surfactant by ventilation, adrenergic mediators, and prostaglandins in the rabbit. Am. Rev. Resp. Dis. 117 (1978) 879

[23] PAPAgeorgiou, A. N., M. F. Desgranges, M. MASSON et al.: The antenatal use of betamethasone in the prevention of respiratory distress syndrome: A controlled double blind study. Pediatrics 63 (1978) 879

[24] PlatZKER, A. C. G., J.A. KitTermaN, E. J. MESCHER et al.: Surfactant in the lung and tracheal fluid of the fetal lamb and acceleration of its appearance by dexamethasone. Pediatrics 56 (1975) 554

[25] POSSMAYER, F., P. CASOLA, F. CHAN et al.: Glucocorticoid induction of pulmonary maturation in the rabbit fetus. The effect of maternal injection of betamethasone on the activity of enzymes in fetal lung. Biochim. Biophys. Acta. 574 (1979) 197

[26] POST, M., J.J.BATENBURG, L.M.G. VAN GOLDE: Effects of cortisol and thyroxine on phosphatidylcholine and phosphatidylglycerol synthesis by adult rat lung alveolar type II cells in primary culture. Biochim. Biophys. Acta. 618 (1980) 308

[27] ROONEY, S. A., L. I. GOBRAN, P. A. MARINO et al.: Effects of betamethasone on phospholipid content, composition and biosynthesis in the fetal rabbit lung. Biochim. Biophys. Acta. 572 (1979) 64

[28] SPELlACY, W. N., A. C. CRUZ, W. C. BUHI et al.: The acute effects of ritodrine infusion on maternal metabolism: Measurements of levels of glucose, insulin, glucagon, triglycerides, cholesterol, placental lactogen, and chorionic gonadotropin. Am. J. Obstet. Gynecol. 131 (1978) 637

[29] TAEUSCH, H. W., F. FRIGOLETTO, J. KITZMILLER et al.: Role of respiratory distress syndrome after prenatal dexamethasone treatment. Pediatrics 63 (1979) 64

[30] UNBEHAUM, V.: Effects of sympathomimetic tocolytic agents on the fetus. J. Perinat. Med. 2 (1974) 17

[31] WALTERS, D. V., R. E. OLVER: The role of catecholamines in lung liquid absorption at birth. Pediatr. Res. 12 (1978) 239

[32] WYSZOGRODSKI, J., H.W.TAEUSCH, M.E. AVERY: Isoxsuprine-induced alterations of pulmonary pressure-volume relationship in premature rabbits. Am. J. Obstet. Gynecol. 119 (1974) 1107

Received December 14, 1983. Revised March 9, 1984. Accepted May 9, 1984.

Mikko Hallman

Childrens' Hospital, University of Helsinki Stenbäckinkatu 11

00290 Helsinki 29, Finland 


\section{Albert Schinzel}

\section{Cortalogue of}

Unbalanced
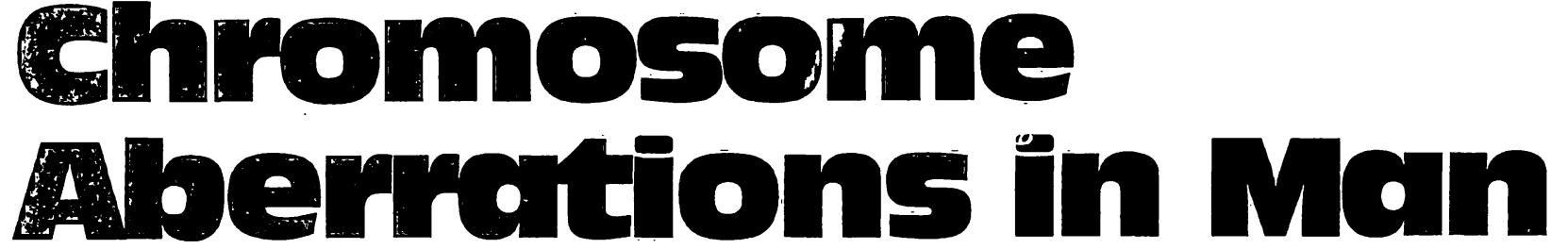

1983. 17 × $24 \mathrm{~cm}$. XVIII, 886 pages. 15 figures. 278 plates. Hardcover. DM 298,ISBN 3110083701

This book presents a comprehensive and updated catalogue of the already large, and rapidly growing number of chromosome aberrations in man. A first section introduces the reader to cytogenetic nomenclature, the normal human karyotype, clinical and epidemiologic features and formation of chromosome aberrations, It is followed by chapters on aberrations of chromosomes 1-22, $\mathrm{X}, \mathrm{Y}$, triploidy and tetraploidy. Each aberration is presented with its clinical findings, course, mental development, outcome and cytogenetic findings. The more frequent aberrations are presented in illustration sections appended to each chromosome chapter. A consistent structure of the text and references provide for rapid orientation. For further study, the more recent and important literature is given for each aberration, up to the end of 1982 . The literature is critically reviewed.

The book is completed by three indices: a list of genes mapped to chromosomes or chromosomal segments, an index of malformations and anomalies, and an author index.
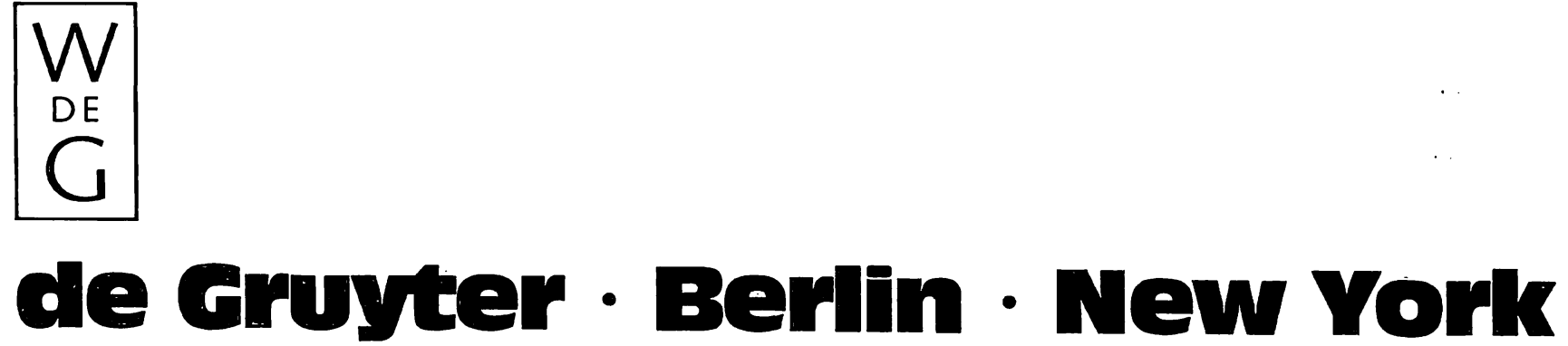